\title{
The Existence of Conditional Sale and Purchase Agreement as The Basis for Transfer of Rights to Land And/or Buildings to Other Party (Analysis Case Of Decisions No.3202/K/Pdt/2016)
}

\author{
Christine Halim ${ }^{1}$, O.K. Isnainul ${ }^{2}$, Kartina Pakpahan ${ }^{3}$, Elvira Fitriyani Pakpahan ${ }^{4}$, Tommy \\ Leonard $^{5}$ \\ \{christinehalim33@gmail.com\} \\ Universitas Prima Indonesia
}

\begin{abstract}
As a preliminary agreement, conditional sale and purchase agreement does not always go according to what the parties have agreed upon. In the process, there are certain conditions that can result in the termination of an agreement, not continued to signing the deed of sale and purchase. As in the case of decisions No.3202/K/Pdt/2016 regarding the buyer who sues the housing developer who according to him has committed contempt of court act by resells the house he had bought to another party without his knowledge. This research is normative juridical with descriptive analysis technique. Theory used is concept of law by Gustav Radbruch, consists of three general precepts: purposiveness, justice, and legal certainty. The conclusion of this paper is the developers acts in accordance with what has been agreed in the agreement which states that the developer can sell the land to another party if the buyer is in default.
\end{abstract}

Keywords: Conditional Sale and Purchase Agreement, Transfer of Conditional Sale and Purchase Agreement, Default, Contempt of Court Act

\section{Introduction}

Conditional sale and purchase agreement is basically a preliminary agreement to buy the property to binding prospective buyers and prospective sellers before the Deed of Sale and Purchase is signed. The agreement arises because construction of flats has not been implemented and many legal requirements in terms of administrative for the sale and purchase have not been fulfilled. From the birth of the agreement, the parties agreed to bind themselves to one another and bound by legal relationship, where one party has the obligation to carry out (the debtor), and the other party has the right to make him run it (creditor). Therefore, it is expected to benefit and protect both the housing developers and buyers.

For that, the government issued a regulation that specifically regulates conditional sale and purchase agreement. This agreement is governed under the guidelines from the Ministry of Public Works and Public Housing of Republic of Indonesia No.11/PRT/M/2019 concerning the Preliminary Agreement System for The Sale and Purchase of Houses, in which the obligation of the conditional sale and purchase agreement is made in the form of a Notarial deed. So that the agreement has legal force as well as legal guarantees if there is a party who breaches the promise, it can no longer evade the obligations that have been determined. This is also in order 
to avoiding conditional sale and purchase agreement that only contain standard clauses that usually benefit the seller.

Despite the parties have agreed and committed to the agreement, there are cases where the conditional sale and purchase agreement ends and is not continued until the signing of the Deed of Sale and Purchase for various reasons. For example, one of the parties' default and cause dispute between the parties that resulted the cancellation of the agreement and leads to a report of default or contempt of court act. As is the case in the decision No.3202/K/Pdt/2016 regarding the buyer who sues the housing developer who according to him has committed contempt of court act by transferring the house he has bought to another party without his knowledge.

The plaintiff initially purchased 12 units of houses to the Defendant with an instalment payment system, and the plaintiff had made regular payments until the 6th Down Payment, which then the Plaintiff stopped the payment because he felt the Defendant did the construction of the house is not in accordance with the progress of the housing development. And indeed, there were financial constraints because the plaintiff's mortgage application was rejected by the Defendant's partner bank.

On that matter, according to the Plaintiff, the Defendant then provides a solution to the Plaintiff to sell the house that he had ordered himself, so that the advance payment and down payment that had been paid by the Plaintiff can be returned through the new buyer. The plaintiff then agreed to sell 1 unit of his house to a new buyer with the defendant's approval. However, the Plaintiff later learned that for the other 11 units of the house which he had paid in instalments, had been sold by the Defendant to a new buyer without his knowledge. The plaintiff felt aggrieved that he could not recover the money he had paid in instalment against the other 11 housing units because it had been sold to another parties.

Based on that, the author is interested in lifting this paper with the title "The Existence Of Conditional Sale And Purchase Agreement As The Basis For Transfer Of Rights To Land And/Or Buildings To Other Party (Analysis Case Of Decisions No.3202/K/Pdt/2016)".

\section{Problem Formulation}

Based on the description above, the limitation of the problem from this legal research can be taken is how the legal consequences of the use of binding agreements as the basis for transferring rights to land and / or buildings to other parties.

\section{Results and Discussion}

\subsection{Legal Protection for Parties Against Default in The Conditional Sale and Purchase Agreement}

Legal protection is a legal guarantee to the parties in conditional sale and purchase agreement, where there is a reciprocal relationship between the parties that leads to a right and obligation to each other. To ensure legal certainty, legal protection is required to protect the parties in performing legal acts. John Austin suggesting that legal certainty is the goal of legal positivism, in which to achieve legal certainty, it is necessary to separate the law from morals to produce a logical, fixed, and closed logical system. The conditional sale and purchase agreement does not always go according to what the parties have agreed upon. In the process, there might be certain conditions arise in the future, for example one of the parties' default, that leads to termination before the deed of sale and purchase agreement is signed. 
A default or a breach of contract, which means the enforcement of the obligation as it should be imposed by the contract, has 3 types, namely:

1. The debtor in no way fulfils the agreement.

2. The debtor is late to fulfil the agreement.

3. The debtor is wrong or unfit to fulfil the agreement.

By not carrying out the obligations of one party will result in the violation of the rights to the other party, so the aggrieved party should require legal protection. Considering the default can be done both from the housing developer and the buyer, both parties should obtain the same legal protection for the common good, here is a legal protection against the parties in the conditional sale and purchase agreement on trade:

\section{Legal protection for developers as business actor}

Legal protection for the developer in conditional sale and purchase agreement is in the form of the agreement itself, the developer usually has presented a standard agreement in which contains clauses in accordance with their wishes. For example, regarding the payment process, payment schedule, and repayment, which is also accompanied by sanctions or fines and the terms of cancellation. The function of the agreement is to proof in Court if one of the party's defaults and to sue based on the agreed clauses. Therefore, if the consumer defaults, the developer can sue him based on the agreement that has been made, considering that the agreement was made and signed by the parties in accordance with the provisions so that the agreement is valid and binding.

Under Article 164 of the HIR, code of civil procedure in Indonesia recognizes the existence of private deed as one of the valid evidences that can be used in Court when a dispute occurs. The private deed has no legal standing in its proving if the parties deny and do not acknowledge the existence of such agreement, while the Notarial deed has the perfect evidentiary power. The private deed is essentially binding on the parties who signed in, but not binding on the judge. However, the power of proof is not as perfect as a Notarial deed, but the power of proof remains as long as the deed is not denied by the parties who made it. This is the main difference between the legal standing of Notarial deed and private deed, because the evidentiary power inherent in the Notarial deed is perfect and binding, not only the parties but also the judge.

In order to provide additional proof power of private deed in the Court can be done legalization by the Notary. Legalization is an acknowledgement or testimony of a Public Official authorized to do so in which case it is a Notary to prove that the documents made by the parties are indeed signed by the parties who made it. With legalization, the notary guarantees the validity of the signatures of the parties involved, thus providing certainty of the legal consequences to the judge regarding the date, identity, and signature of the parties to the agreement.

\section{Legal protection for consumers as buyers}

Consumer protection is held as a joint venture based on 5 (five) principle based on the provisions of Article 2 of Law No. 8 of 1999, namely benefits, fairness, balance, security and safety of consumers, as well as legal certainty. This protection includes protection so that consumers do not obtain goods and/or services that are not in accordance with the agreement or violate the provisions of the Law. Legal Protection for consumers if the developer defaults can be seen in various aspects such as the Civil Code that regulates in general regarding sanctions against an act of default, or according to the Consumer Protection Law which in Article 6 and Article 7 is regulated on the rights and obligations of business actors and according to Article 
16, concerning prohibited acts for businesses that not keep the period of settlement in accordance with the promised agreement and not keep the promise of an achievement.

Generally, the developers have designed clauses contained in the conditional sale and purchase agreement, so generally the clauses in the agreement more protect the interests of developers. So, the position of the consumer is not free and weak, it is not even impossible if the consumer has the compulsion to agree to the agreement that has been made. As well as the clause contains a waiver or limitation of liability determined unilaterally by the developer that is binding and must be fulfilled by the consumer. Therefore, the inclusion of standard clauses carried out by developers is prohibited in Article 18 paragraph 1 of Law No. 8 of 1999 so that the position of consumers is equivalent to business actor.

And through Law No. 8 of 1999 concerning Consumer Protection, consumers have been given the means to protect their rights if they suffer losses as a result of the actions of developers as business actor. In article 45 of Law No. 8 of 1999 concerning Consumer Protection, it is stated that any harmed consumer can sue business actor through institutions tasked with resolving disputes between consumers and businesses or through the judiciary in the general judicial environment. And Consumer dispute resolution can be reached through the Courts or outside the Court based on the voluntary choice of the parties to the dispute.

As a legal basis, Law No. 8 of 1999 that provides protection to consumers and developers needs to be realized by both parties. Although Law No. 8 of 1999 prioritizes the interests of consumers, it does not mean that this rule will immediately harm the developer in conducting its business. Law No. 8 of 1999 will provide legal certainty to both parties, by describing the rights and obligations of the parties, it will further affirm the position of each party so as to protect the interests of each party.

Legal protection for consumers requires the relevant parties in it to support its implementation, such as developers as business actor, consumers, governments, consumer institutions both private and government-owned. If all parties can cooperate and optimize their respective roles, it can provide maximum consumer protection efforts to the desired rights.

\section{Transfer of Rights in Conditional Sale and Purchase Agreement}

Based on the Circular letter of the Supreme Court (SEMA) No.4 of 2016, the transfer of land rights based on the conditional sale and purchase agreement legally occurs if the buyer has paid the full amount of the house and in good faith controlled it, then legally the transfer of land rights from the seller to the buyer has occurred. This is in accordance with the principle of the binding agreement, in which the parties agree that the rights to the land will be transferred to the buyer when the terms of the making of Deed of Sale and Purchase can be fulfilled.

Generally, the transfer of rights and obligations to the conditional sale and purchase agreement can be done by making a rights transfer agreement between the old buyer and the other party as the new buyer with the developer's notice and approval and must comply with the terms and conditions of the signed agreement. Transfer of rights agreement is a legal act aimed at transferring or transferring the right of the conditional sale and purchase agreement from one party to the other party, from the previous buyer stated in the agreement, to the new buyer. Thus, the new buyer will replace the previous buyer's position in the binding agreement with the developer.

The transfer of rights agreements can also be through take over credit by making a debt transfer agreement (novasi), as stipulated in Article 1413 paragraph (2) jo. Article 1415 of the Civil Code. The takeover credit is done by means of debt renewal, in which the new buyer is appointed to replace the old buyer. So, the old buyer was exempt from his alliance with the developer, the new debtor will then pay and be responsible for all payments on the house. Thus, 
if all the requirements to sign the Deed of Sale and Purchase have been fulfilled, it will be able to be done directly by the new buyer with the developer.

The novasi or renewal of debt is one of the deletions of the alliance, which is referred to as novasi is a process of changing the old contract by a new contract, which causes the old contract to be terminated, so that the next valid contract is a new contract with changes to the terms and conditions or by changes to the parties to the contract.

\section{Cancellation of Conditional Sale and Purchase Agreement}

1. Causes of Cancellation of Conditional Sale and Purchase Agreement

The conditional sale and purchase agreement is the preliminary agreement of the parties before the sale and purchase transaction, the purpose of which is binding on the parties, to keep the agreement carried out properly while the requested terms can still be taken care of until the conditions for buying and selling have been met. After the conditions for buying and selling have been fulfilled, it will be continued with the signing of the Deed of Sale and Purchase. However, in the process of an agreement does not always run-in accordance with what has been agreed by the parties who made it, there are certain conditions that can result in the termination of an agreement and not continue until the signing of the Deed of Sale and Purchase. Here are the things that can result in the cancellation of the conditional sale and purchase agreement:

a. Default

As the conditional sale and purchase agreement has been signed means both parties, the developer and the buyer have agreed to the contents of the agreement. Therefore, each party must carry out its rights and obligations in accordance with what has been promised. The non-fulfilment of the rights or obligations by one of the party may cause differences of understanding between the parties, thus causing the cancellation of the binding agreement.

b. Not in good faith

The conditional sale and purchase agreement create a reciprocal obligation to the parties who make the agreement. The parties have a good faith obligation means the obligation to notify and explain the material facts of the object of the agreement and the obligation to examine the object of the agreement and the clauses of the agreement before entering into an agreement and binding on the agreement. In this case, the buyer is obliged to research related to the promised object. Instead, developers have an obligation to explain all information relating to the object promised to the buyer. Therefore, after being bound by a binding agreement, the parties shall perform their obligations as stipulated in the agreement. Buyers are required to make payments and developers are required to complete the construction and sign the Deed of Sale and Purchase in accordance with the agreed time. If either party is not in good faith to perform its obligations, then the agreement may be void.

c. Void at law

The conditional sale and purchase agreement is declared void at law if it does not meet the terms of the validity of the agreement as specified in Article 1320 of the Civil Code. In addition, the creation of a conditional sale and purchase agreement on trade must also be in accordance with the ministerial regulations Number 11/PRT. M/2019. In addition, an agreement may be cancelled by a request from the party wishing to, such as the parent, guardian, or guardian shall be said to be a relative cancellation or an absolute cancellation, which may be divided into:

- cancellation by filing a lawsuit with the judge (Article 1446 of the Civil Code).

- cancellation by the judge through a decision (Article 1449 of the Civil Code). 
- Legal Consequences of Cancellation of Conditional Sale and Purchase Agreement

A deal in an agreement is considered to have been happen when one of the parties has accepted or undertaken the offer made by the other party. An agreement that has been made cannot be modified or cancelled unilaterally without the consent of the other party. Parties who don't fulfil their obligations will be penalized to pay compensation or fines to the aggrieved party for each day of delay, based on what has been agreed by both parties, either the seller to the buyer or the buyer to the seller. The fine must be paid instantly and at once.

The legal consequence arising from the cancellation of conditional sale and purchase agreement is the agreement will be terminated because the parties have cancelled the agreement that has been made, the legal relationship between the parties ends and is no longer bound to one another. However, if the parties do not get a solution to the problem, the aggrieved party can sue the party that caused the loss in Court. If both parties agree to the cancellation, the preferred route would be returned to what it was before the agreement existed.

\section{Dispute Resolution}

Settlement of disputes over the conditional sale and purchase agreement can be done in 2 ways:

1. Litigation Settlement (Through the Court)

Litigation is a process of dispute resolution in Court, where the disputing parties face each other to defend their rights in Court. Where the solution is in the form of a judge's decision that provides a win-lose solution. Based on law of contract, the aggrieved party can file a civil suit at the local District Court on 2 grounds:

a. Defaults

The lawsuit for default is based on the existence of a breach of contract committed by one of the parties in conditional sale and purchase agreement, so that the aggrieved party sues to the Court to demand compensation for expenses, losses, and penalties caused by the default, as stated in Article 1243 and Article 1244 of the Civil Code. The obligations to pay compensation does not automatically arise when one of the parties is negligent, there must be a statement of negligence from the aggrieved party. This is in accordance with Article 1238 in conjunction with Article 1243 of the Civil Code.

b. Contempt Of Court

Contempt of Court lawsuit is a lawsuit for compensation due to a Contempt Of Court act that results in losses to other people. Based on Article 1365 of the Civil Code, every person has the right to demand compensation for a Contempt of Court act that has harmed him. According to Jurisprudence, the provisions regarding compensation that must be paid due to illegal actions can follow the provisions of compensation for default (Article 1243 of the Civil Code), this is because the Civil Code does not specifically regulate provisions regarding compensation for Contempt of Court.

Cancellation of an agreement through the Court can be done if one of the parties feels aggrieved, the legal sanction for the cancellation of the agreement in Court is effective after a Court decision has permanent legal force.

2. Non-Litigation Settlement (Out of Court)

Due to the lengthy and time-consuming Court process, the Consumer Protection Law provides an alternative way by providing dispute resolution outside if the Court, with the aim of making it easier for the disputing parties. Out of Court dispute resolution is regulated through Law Number 30 of 1999 concerning Alternative Dispute Resolution and Article 45 paragraph 2 in 
conjunction with Article 47 of Law Number 8 of 1999 concerning Consumer Protection. There are 2 types of dispute resolution outside the Court:

a. Through Amicably Settlement

Amicable Settlement is where the disputing parties resolving their problems by deliberation to reach a consensus without going through Court or Consumer Dispute Resolution Agency. The disputing parties will resolve it amicably, by determining a solution until an agreement is agreed by both parties. If no deal is reached, the parties can submit the lawsuit to the Court through the help of a consumer dispute resolution agency.

b. Through the Consumer Dispute Resolution Agency

Settlement of consumer disputes can also be carried out through the consumer dispute resolution agency as regulated in Article 49 to 58 of Law Number 8 of 1999 concerning consumer protection.

The Consumer Dispute Resolution Agency is regulated in Law Number 8 of 1999 concerning Consumer Protection in Chapter XI Article 49 to Article 58. This agency is a small Court (small claim Court) which was formed to resolve consumer disputes outside the Court by producing decisions quickly, simple and inexpensive in accordance with the principles of justice. Quickly because it has to give a decision within a maximum of 21 working days (Article 55), without any appeal offer which can prolong the process of implementing the decision (Article 56 and Article 58). Simple because the settlement process can be done by the disputing parties themselves, and cheap because the costs incurred to undergo the trial process are very low.

The consumer Dispute Resolution Agency is carried out in 3 ways:

1. Conciliation

In Article 1 Number 9 of the Decree of Minister of Industry and Trade of the Republic of Indonesia Number 350/MPP/Kep/2001 concerning the Implementation of Duties and Authorities of The Consumer Dispute Resolution Agency, it is explained that conciliation is the process of resolving consumer disputes outside the Court intermediary by The Consumer Dispute Resolution Agency to bring together the disputing parties and assisted by a conciliator, and the settlement is submitted to the disputing parties.

2. Mediation

In Article 1 Number 10 of the Decree of Minister of Industry and Trade of the Republic of Indonesia Number 350/MPP/Kep/12/2001 concerning the Implementation of Duties and Authorities of The Consumer Dispute Resolution Agency, it is explained that mediation is the process of resolving consumer disputes outside the Court intermediary by of The Consumer Dispute Resolution Agency act as intermediaries and advisors as mediators, and the settlement is submitted to the disputing parties.

3. Arbitration

In Article 1 Number 11 of the Decree of Minister of Industry and Trade of the Republic of Indonesia Number 350/MPP/Kep/12/2001 concerning the Implementation of Duties and Authorities of The Consumer Dispute Resolution Agency, it is explained that Arbitration is an out-of-court consumer dispute resolution process in which the dispute parties delegate the settlement fully to The Consumer Dispute Resolution Agency.

Article 45 paragraph 4 of the Consumer Protection Act, governing the provision that states a lawsuit through a court can only be taken if the efforts to resolve the consumer dispute outside the court are declared unsuccessful by the dispute parties. 


\section{Conclusion}

The transfer of the binding agreement to another party or also known as the credit oper can be done by making a debt transfer agreement (novasi) as stipulated in Article 1413 paragraph (2) jo. Article 1415 of the Civil Code. As a result of the law the transfer resulted in the previous agreement being deleted, so that the next applicable agreement is a new agreement with a change in the subject matter of the law in the agreement. Where the old buyer is exempt from the agreement with the developer then the new buyer will pay and be responsible for all payments for the house to the developer. The transfer of such agreement can only be done with the knowledge and consent of the developer.

\section{References}

[1] Herline Budiono, Ajaran Umum Hukum Perjanjian dan Penerapannya dibidang Kenotariatan, PT Citra Aditya Bakti, Bandung, 2010.

[2] Lukman Santoso Az, Hukum Perikatan (Teori Hukum dan Teknis Pembuatan Kontrak, Kerja Sama, dan Bisnis), Setara Press, Malang, 2016.

[3] Mariam Darus Badzulraman (et.al.), Kompilasi Hukum Perikatan, Bandung: PT Citra Aditya Bakti, Bandung, 2001.

[4] Nurnaningsih Amriani, Mediasi Alternatif Penyelesaian Sengketa di Pengadilan, Grafindo Persada, Jakarta, 2012.

[5] Projodikoro dan R.Wirjono, Asas-Asas Hukum Perjanjian, Sumur, Bandung, 2003.

[6] Ridwan Khairandy, Iktikad Baik Dalam Kebebasan Berkontrak, Cetakan Kedua, Program Pascasarjana Fakultas Hukum Universitas Indonesia, Jakarta, 2004.

[7] Rosa Agustin (et.al.), Hukum Perikatan (Law of Obligations), Jakarta: Pustaka Larasan, 2012.

[8] Sarwono, Hukum Acara Perdata Teori Dan Praktik, Sinar Grafika, Jakarta, 2011.

[9] Titik Triwulan Tutik, Pengantar Hukum Perdata Di Indonesia, Prestasi Pustaka Publisher, Jakarta, 2006.

[10] Widodo Dwi Putro, Kritik Terhadap Paradigma Positivisme Hukum, Genta Publishing, Yogyakarta, 2011.

[11] Yahya Harahap, Segi-Segi Hukum Perjanjian, Alumni, Bandung, 1986.

[12] Maman Djafar, "Kekuatan Hukum Akta Di Bawah Tangan Dalam Praktek Di Pengadilan”, Lex Privatum, Vol. III/No. 4/Okt/2015, hal.107-108, 2015.

[13] Ayu Riskiana Dinaryanti, "Tinjauan Yuridis Legalisasi Akta Di Bawah Tangan Oleh Notaris“, Jurnal Ilmu Hukum Legal Opinion Edisi 3, Volume 1, Tahun 2013.

[14] Santosa, K., dan Hanim, L, "Perlindungan Hukum Bagi Pihak-Pihak Yang Beritikad Baik Dalam Pembatalan Perjanjian Jual Beli Tanah Dan Bangunan (Studi Kasus Nomor 29/Pdt. G/2014/PN. Wsb)", Jurnal Akta, 4(2), 167-173. hal.168, 2017.

[15] Retno Puspo Dewi (et.al.), "Pembatalan Akta Perjanjian Pengikatan Jual Beli Akibat Wanprestasi (Studi Kasus Putusan Nomor: 200/Pdt.G/2012/PN.Jkt.Sel)”, Jurnal Repertorium Volume IV No.2 Juli - Desember 2017, hal.148, 2017.

[16] Yunik Sri Antari, "Pembatalan Perjanjian Pengikatan Jual Beli Hak Milik Atas Tanah", Acta Comitas, Vol.03 No.02 Oktober 2018, hal. 289, 2018.

[17] Muh. Taufiq Amin, "Konsekuensi Hukum Pembatalan Akta Perjanjian Pengikatan Jual Beli ( PPJB) Dalam Praktek Jual Beli Properti Di Makassar”, Jurisprudentie Vol.5 No.1 Juni 2018, hal. 261, 2018.

[18] Hj. Muskibah, “Analisis Mengenai Cara Penyelesaian Sengketa 